\section{Between tragedy, romance, comedy and satire: narratives of axiological progress in public relations}

\author{
Peter Winkler and Jannik Kretschmer \\ Department of Communication Studies, University of Salzburg, \\ Salzburg, Austria, and \\ Michael Etter \\ King's Business School, King's College London, London, UK
}

Narratives of axiological progress in $\mathrm{PR}$

\begin{abstract}
Purpose - Over recent years, public relations (PR) research has diversified in themes and theories. As a result, PR presents itself today as a multi-paradigmatic discipline with competing ideas of progress that mainly circle around questions of ontology and epistemology, i.e. around defining appropriate object and knowledge in PR research.

Design/methodology/approach - This conceptual article highlights a third crucial question underlying the debate drawing on a narrative approach: The question of axiology, hence, the normative question how PR research shall develop to contribute to societal progress.

Findings - The article presents a model, which describes how normative visions of progress in different PR paradigms - functional, co-creational, social-reflective and critical-cultural - manifest in each distinct combinations of four narrative plots - tragedy, romance, comedy and satire.

Originality/value - These findings complement the current debate on disciplinary progress in PR research by fostering reflection and debate on paradigm development and cross-paradigmatic tensions and exchange from an explicit axiological perspective.
\end{abstract}

Keywords Axiology, Narrative approach, Disciplinary progress, Paradigms, Public relations

Paper type Conceptual paper

Over recent years, the field of public relations (PR) research has diversified in themes and theories (Ferguson, 2018 [1984]; Pasadeos et al., 2010; Sallot et al., 2003; Sisco et al., 2011) and today presents itself as a multi-paradigmatic discipline (Bardhan and Weaver, 2010; Curtin, 2012; Edwards, 2012). Interpretations of what this multi-paradigmatic state means for disciplinary progress, however, considerably vary and preliminarily circle around two analytic dimensions: On the one hand, scholars debate the ontological dimension, addressing the question how to progress from defining a proper object in PR research; on the other hand, scholars debate the epistemological dimension, addressing the question how to progress from acquiring rigorous and relevant knowledge in PR research. Based on these reflections, some scholars promote disciplinary consilience and consolidation of one PR-paradigm as basis of progress (Botan and Taylor, 2004; Ferguson, 2018 [1984]; Grunig, 2018; Nothhaft, 2016; Zerfass et al., 2018), while others propose to overcome paradigmatic either-or-thinking and

(C) Peter Winkler, Jannik Kretschmer and Michael Etter. Published by Emerald Publishing Limited. This article is published under the Creative Commons Attribution (CC BY 4.0) licence. Anyone may reproduce, distribute, translate and create derivative works of this article (for both commercial and noncommercial purposes), subject to full attribution to the original publication and authors. The full terms of this licence may be seen at http://creativecommons.org/licences/by/4.0/legalcode

This papers forms a part of special section "EUPRERA Congress 2020 - Latest research on Public Relations and Communication”, guest edited by Einwiller Sabine.

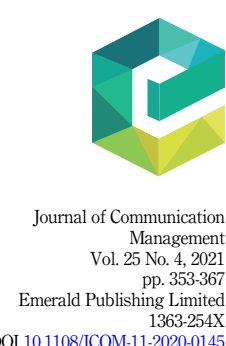

DOI 10.1108/JCOM-11-2020-0145 
$\mathrm{JCOM}$ 25,4

embrace the current multi-paradigmatic state of $\mathrm{PR}$ as a basis of further disciplinary progress instead (Curtin, 2012; Edwards, 2012; Gower, 2006; Ihlen and Fredriksson, 2018; Ihlen and van Ruler, 2007). These reflections on progress often draw on sophisticated science theoretical debates, tend to remain on the level of programmatic calls and have difficulties explaining the development of and relation between paradigms in PR research based on ontological and epistemological reasoning alone.

Inspired by a today mostly forgotten article by Pearson (1990) and a more recent suggestion by Curtin (2012), this conceptual article seeks to shed light on a third, so far less considered dimension to reflect on disciplinary progress: the axiological dimension. It addresses the normative question of how PR research shall develop to contribute to societal progress. Highlighting the axiological dimension can provide a complementary explanation to the question what drives paradigm development in PR scholarship, and it allows for reflection on normative reasons of cross-paradigmatic tensions and exchange. However, as normative convictions tend to remain implicit, we propose a narrative approach (Czarniawska, 2004; Fisher, 1994; White, 1980). This narrative approach helps to reconstruct and explicate specific narrative plots and tropes (White, 1975) that ground normative visions of progress constitutive for specific PR paradigms.

The contribution of this conceptual article is threefold: First, we inform the current debate on disciplinary progress in PR research, which is largely focused on questions of ontology and epistemology, by highlighting the additional explanatory value of axiological convictions underlying this debate. Choosing this focus, however, does not imply that we consider our perspective exclusive or superior to extant explanations. Quite the contrary, our aim is complementary, as we hope our reflections may contribute to a more inclusive future debate on progress in PR research, which has all three dimensions - ontology, epistemology and axiology and their interrelations in mind. Second, we develop a model and propose how distinct combinations of four narrative genres - tragedy, romance, comedy and satire - can serve as indicators to identify specific normative convictions of progress driving paradigm development in future empirical PR research. We further hope, third, that our model may also provide PR scholars, practitioners and students with a fresh perspective to reflect on their normative convictions, and to debate these convictions with fellows, particularly those with opposing views.

In the next section, we will therefore provide a brief overview of the current paradigmatic approach to ontological and epistemological progress in PR research, before introducing a complementary narrative approach, which allows for a better understanding of implicit normative convictions of progress. Based on this narrative approach, we will unfold a model, which parses these visions of progress in PR paradigms according to their underlying narrative plots and tropes. The article closes with a discussion on how our model can inform the recent debate on progress in PR research.

\section{A paradigmatic approach to progress in PR research}

Both longitudinal content (Botan and Taylor, 2004; Ferguson, 2018 [1984]; Sallot et al., 2003; Sisco et al., 2011) and citation analyses (Pasadeos et al., 2010) reveal that themes and theories have diversified considerably over the last decades in the field of PR research. The question, if diversification also leads to disciplinary progress is however contested. This manifests in divergent propositions ranging from calls for paradigmatic consilience (Ferguson, 2018 [1984]; Grunig, 2018), over attempts to overcome the dominant functional paradigm (Botan and Taylor, 2004; Gower, 2006; Ihlen and van Ruler, 2007), to recent suggestions to accept the current multiparadigmatic state of PR research as a fruitful "new normal" (Curtin, 2012; Edwards, 2012).

Kuhn's concepts of paradigm and progress

Most of the scholarship on disciplinary progress in PR research rests on different readings of Thomas Kuhn's (Kuhn, 2012 [1962]) paradigmatic approach to scientific progress and its 
vivid, yet ambiguous reception, particularly in the social sciences (Rule, 1997). Partly, this ambiguous reception is due to Kuhn's vague definition of what constitutes consilience in a research paradigm. Masterman (1970) counts over 20 different constitutive features in Kuhn's original work, yet analytically aggregates them on three dimensions: The "sociological" dimension contains professional consent on the overall object, scope and limits of a paradigm, also comprising mechanisms of scholarly reward and sanctioning. It corresponds with the ontological dimension (What do we study?). The "artifact" dimension is understood as a shared set of theories, tools and methods, which scholars apply to define and solve research problems, which corresponds with the epistemological dimension (How do we study?). Finally, the "metaphysical" dimension represents normative "ways of seeing" the world as well as a "set of beliefs" (Masterman, 1970, p. 65) within a paradigm, which is deeply internalized and often remains implicit. It corresponds with the axiological dimension (What do we value?).

For the natural sciences, Kuhn argues that paradigmatic consilience in a particular field is crucial to establish the state of "normal science". Epistemological, ontological and axiological questions are no longer debated, and scholars can focus on solving specialized research problems and contribute to incremental, yet steady progress. Kuhn also critically points out that paradigmatic consilience over time can lead to crisis, as inner-paradigmatic blind spots and incommensurable problems cumulate. This is when Kuhn (2012 [1962]) sees chances for "scientific revolutions", often initiated by scholars from the margins or outsiders, who fundamentally challenge an established paradigm and propose alternatives, which can lead to leaps in progress in the natural sciences.

However, Kuhn is skeptical if his concept of normal science and scientific revolutions applies to progress in the social sciences (Kuhn, 1991, p. 24). This is the case, because their object of study is also an object of intervention, and hence in constant transformation. Accordingly, disciplines in social sciences shall rather be considered as in a state of ongoing multi-paradigmatic immaturity, where consilience is never reached and progress rather emerges from cross-paradigmatic tensions and exchange.

In the following, we briefly sketch how different readings of Kuhn's reflections mirror in current debates on ontological and epistemological progress in different PR paradigms. The below presented paradigms represent self-designated labels by PR scholarship, not fullfledged paradigms in a Kuhnian sense.

\section{Paradigms and progress in $P R$ research}

The so-called functional paradigm in PR research has the longest tradition. Its adherents in $\mathrm{PR}$ research and spin-offs such as communication management, corporate communications and strategic communication call for paradigmatic consilience most explicitly. The functional paradigm roots in ontological efforts to establish PR as genuine management function (e.g. Broom et al., 2013; Grunig and Grunig, 1992; Tench et al., 2017). Particularly in recent years, these efforts get complemented and partly overlaid by epistemological efforts to reinvent the discipline as an applied science that focuses on developing positivist research designs and methods to detect and predict causes and effects of behavioral change (e.g. Grunig, 2018; Nothhaft, 2016; Nothhaft et al., 2018; Seiffert-Brockmann, 2018; Zerfass et al., 2018) - often directly inspired by recent reflections on disciplinary maturation and consilience in the natural sciences (Shneider, 2009; Wilson, 1998).

Already since the 1980s, the functional paradigm has been contested by PR scholars representing the so-called co-creational paradigm (Botan and Taylor, 2004). These scholars echo Kuhn's idea of progress through revolting against the established paradigm. Among the first, Ferguson (2018 [1984]) calls for less management centric but public and relationshiporiented ontological positioning of the PR discipline. In a similar vein, drawing on counterfactual principles, dialogic (e.g. Kent and Taylor, 2002; Taylor and Kent, 2014) and 
$\mathrm{JCOM}$

25,4

community-centered approaches (e.g. Hallahan, 2016; Kruckeberg and Starck, 1988) challenge the management centrism of the functional paradigm and its underlying instrumental approach to communication. On the epistemological level, these approaches emphasize the transformative properties of communication as symbolic meaning making system and reflect on how communication can contribute to mutual understanding and reciprocity orientation on a way toward a "fully functioning society" (Heath, 2018).

Further, there is a growing body of scholarship performing under the label of a socialreflective paradigm (Ihlen and Verhoeven, 2012; see also Ihlen and Fredriksson, 2018; Ihlen and van Ruler, 2007). This scholarship criticizes the functional paradigm to systematically overrate the instrumental capacities and impact of PR as a discipline. This critique is particularly promoted by scholars, who build on social theories and ontologically seek to reconstruct disciplinary development and practice of PR as an effect of the wider societal context (e.g. Falkheimer, 2007; Fredriksson et al., 2013; Holmström, 2018). Epistemologically, this scholarship places emphasis on describing PR as a communicatively precarious and complex, rather than as deliberate and predictable organizational practice (e.g. Christensen and Langer, 2009; Gulbrandsen and Just, 2016; Heide et al., 2018; Wehmeier, 2006).

Even more fundamental contestation of the functional paradigm can be found in explicitly critical scholarship (e.g. L'Etang et al., 2016; Miller and Dinan, 2008; Roper, 2005). It challenges the functional paradigm by placing ontological emphasis on its crucial role in supporting global hegemony and the reproduction of structural inequalities on the societal, organizational and individual level. In recent years, and informed by cultural studies and poststructuralist reasoning, this line of scholarship places growing epistemological emphasis on the deconstructive properties of PR as counter-hegemonic practice (e.g. Berger, 2005; Davidson, 2016; Holtzhausen, 2012). This line of thought trades under the label of a criticalcultural paradigm (e.g. Curtin and Gaither, 2005; Edwards, 2018).

This brief overview of PR paradigms allows for four preliminary conclusions. First, the contestation of the most established functional paradigm by alternative propositions - cocreational, social-reflective and critical-cultural - has led to the current multi-paradigmatic state of PR research. Second, existing paradigms do not replace each other, but they co-exist in tense relationships. Third, disciplinary consilience among these paradigms is lacking, rather they vindicate their respective ontological and epistemological positions. Fourth, these positions are largely imported from other disciplines (Dühring, 2015), and their specific assemblage and adaption within paradigms are far from self-explanatory from an ontological and epistemological perspective alone.

The current emphasis on the ontological and epistemological dimension, hence, may not be sufficient to fully grasp what drives the current debate on disciplinary progress in PR scholarship - neither with regard to efforts that strive for paradigmatic consilience (e.g. Dühring, 2015; Nothhaft, 2016; Sisco et al., 2011), nor those interpreting the current multiparadigmatic state as a chance of cross-fertilization (e.g. Bardhan and Weaver, 2010; Edwards, 2012; Gower, 2006). Accordingly, we follow a recent proposition by Curtin, who argues that in the domain of PR research, paradigm development and exchange does not necessarily depend on ontological and epistemological coherence, but that positions "share some basic values (i.e. axiological principles)" (Curtin, 2012, p. 42). Still, drawing on Kuhn, Curtin also cautions that addressing this axiological dimension is a fickle endeavor, as normative convictions of progress underlying scholarly positions often remain implicit. Challenging them rather depends on "a leap of faith" (Curtin, 2012, p. 39) than it is the object of deliberate reflection and debate. The aim of the remainder of this paper is hence to propose a way to explicate this implicit axiological dimension. To do so, we introduce a narrative approach, which shall help to reconstruct normative convictions underlying PR paradigms, and thereby make them accessible to future reflection and debate on progress in $\mathrm{PR}$ research. 


\section{Introducing a narrative approach}

Narrative reasoning is not new to PR research when it comes to analyzing particular application areas such as corporate identity, storytelling, risk communication, public targeting or strategizing (e.g. Johansen, 2012; Kent, 2015; Palmlund, 2009; Vasquez, 1993; Winkler and Etter, 2018). The idea that narratives represent a vital source to raise recognition, identification and mobilization for a particular world view (Burke, 1969) is hence established in PR research. The idea, however, to apply this consideration to normative convictions of progress in the own field of research has received little systematic reflection so far. Indeed, Pearson's (1990) "Perspectives on Public Relations History" already pointed into this direction, but it is mostly forgotten today. Pearson argues how competing reconstructions of PR history always also represent the normative convictions of the historians, hence their belief of how society shall develop, rather than a mere analysis of historical facts. We revive this idea applying an explicitly narrative lens and broaden it toward envisioned progress in PR research.

\section{A narrative approach to disciplinary progress}

The idea that disciplinary progress depends not only on ontological and epistemological rigor and relevance but also on convincing narratives, harks back to Ludwik Fleck's "The Genesis and Development of a Scientific Fact" (1981 [1935]). Fleck's publication is considered foundational because it explains the development of scientific progress as closely related to the formation of "thought collectives" around a shared "thought style", which shall later inspire Kuhn's paradigmatic approach. Fleck, however, further argues that the establishment of scientific findings as facts equally depends on well-crafted narratives - concretely prescientific "proto-ideas", i.e. everyday stories about a particular phenomenon that are vital to promote and legitimate scientific ideas. Also, narrativist Fisher (1994) echoes the importance of narratives to communicate scientific achievement and progress.

The most prominent representative of a narrative approach to progress in the social sciences is Hayden White. In his publication "Metahistory", White (1975) unfolds the provocative idea that the leading historical and social philosophical schools of the nineteenth century, despite their intention to provide objective analysis and representation, adhere to implicit narrative patterns that promote particular axiologies, i.e. normative convictions of how society shall progress. White thereby distinguishes four ideal-typical narratives, which today find vivid application in history, philosophy and the social sciences (Czarniawska, 2004; McCloskey, 1998). White's four narratives build on distinct plots and tropes. Plots equal four established dramatic genres (Frye, 1957): tragedy, comedy, romance and satire. They correspond with four rhetorical tropes: metonymy, synecdoche, metaphor and irony (Burke, 1941). Taken together, these plots and tropes allow unfolding four ideal-typical normative narratives of societal progress.

\section{Four narratives of progress}

The first narrative follows the plot of the tragedy. Here, higher forces, such as cosmic laws or divine providence, dictate how things develop. The progress of the story is predetermined by fate, while efforts to escape this fate remain delusion. Tragic plots get reinforced by the use of metonymy as preferred trope (Panther and Radden, 1999), and hence figurative speech, which builds on reasoning of cause and effect to emphasize the deterministic logic that drives the plot.

In narratives with a comedy plot, agents are also at the mercy of higher forces. Yet, the progress of the story manifests in a complex cascade of trials and tribunals, in which agents are constantly contested, yet ultimately find salvation when things go up in smoke toward a desired end (Frye, 1957). The plot thus follows an inscrutable development, which only
Narratives of axiological progress in PR 
$\mathrm{JCOM}$ 25,4

\section{8}

unveils from an integrative look at the "bigger picture". This perspective is affirmed by frequent use of synecdoche, and hence figurative speech that builds on pars-pro-totoreasoning (Hamilton, 1990).

While tragedy and comedy provide structural narratives, the latter two narratives romance and satire - are agentic by nature. In romantic plots, story progress depends on the maturation of central agents. Romance can either emphasize the maturation of a chosen individual - a classic hero's journey (Campbell, 2008 [1949]; Jameson, 1975) - or the maturation in a romantic relationship (Jameson, 1975). In both manifestations, progress depends on overcoming established behavioral patterns, accepting the challenge to conquer the unknown, achieving extraordinary virtues and skills and eventually change the destiny of all. This romantic idea of progress finds support by the trope of metaphor (Lakoff and Johnson, 1980). It stands for figurative language describing "something in terms of something else" (Burke, 1969, p. 228) attributing characteristics to agents that transcend their initial character.

Satirical plots, ultimately, are also agentic, yet fundamentally challenge the idea of linear story progress as it is established in tragic, comic and romantic narratives. Rather, satire seeks to unmask expectations in linear progress as illusion. Alternatively, it emphasizes the transformative potential that lies in the situational irritation and subversion of established expectations, thereby revealing their inherent contradiction and instability (Watson, 2015). To do so, satire frequently uses the trope of irony (Booth, 1975), a figurative language that conveys counter-intuitive and contrary meaning and thus breaks common sense.

Table 1 provides an overview of the four narratives.

While in earlier writings, White (1975) parses historical and social philosophical positions according to one of these four ideal-typical narratives, in later writings he stresses that the most convincing narratives of progress build on a combination of structural and agentic plots and tropes, i.e. a combination of tragedy or comedy on the one hand, and romance or satire on the other hand (Grinter, 2017; White, 1980).

\section{Narratives of progress in PR paradigms}

In the following, we unfold in a model how White's considerations allow for reconstructing normative convictions of progress underlying extant PR paradigms. Concretely, we show how a specific combination of distinct narrative features (plot, trope, story driver) of tragedy, comedy, romance and satire shape normative convictions of how PR research shall develop in the functional, co-creational, social-reflective and critical-cultural paradigm, respectively. We illustrate our reflections citing exemplary literature representing these paradigms, which may serve as an inspiration for future empirical research that seeks to follow our narrative approach to tract normative convictions of progress in PR research.

Figure 1 provides an overview. Each quadrant (Q1-4, clockwise) represents a paradigm, the adjoining axes (A1-4) represent the narrative plots, tropes and story drivers they combine.

\section{Narrating progress in the functional paradigm: between tragedy and romance}

The vision of axiological progress in the functional paradigm (Q1) follows an oscillation between tragic and romantic plot, concretely fatalism and heroism as key drivers of story

\section{Table 1.}

Plots, tropes and drivers of progress in White's (1975) metahistories

\begin{tabular}{|c|c|c|c|c|}
\hline Plot & $\begin{array}{l}\text { Tragedy } \\
\text { (structural) }\end{array}$ & $\begin{array}{l}\text { Comedy } \\
\text { (structural) }\end{array}$ & $\begin{array}{l}\text { Romance } \\
\text { (agentic) }\end{array}$ & $\begin{array}{l}\text { Satire } \\
\text { (agentic) }\end{array}$ \\
\hline Trope & $\begin{array}{l}\text { Metonymy } \\
\text { (causality) }\end{array}$ & $\begin{array}{l}\text { Synecdoche } \\
\text { (pars pro toto) }\end{array}$ & $\begin{array}{l}\text { Metaphor } \\
\text { (analogy) }\end{array}$ & $\begin{array}{l}\text { Irony } \\
\text { (contradiction) }\end{array}$ \\
\hline Drivers & Delusion and fate & $\begin{array}{l}\text { Complex contestation and } \\
\text { salvation }\end{array}$ & $\begin{array}{l}\text { Heroic or relational } \\
\text { maturation }\end{array}$ & $\begin{array}{l}\text { Irritation and } \\
\text { subversion }\end{array}$ \\
\hline
\end{tabular}




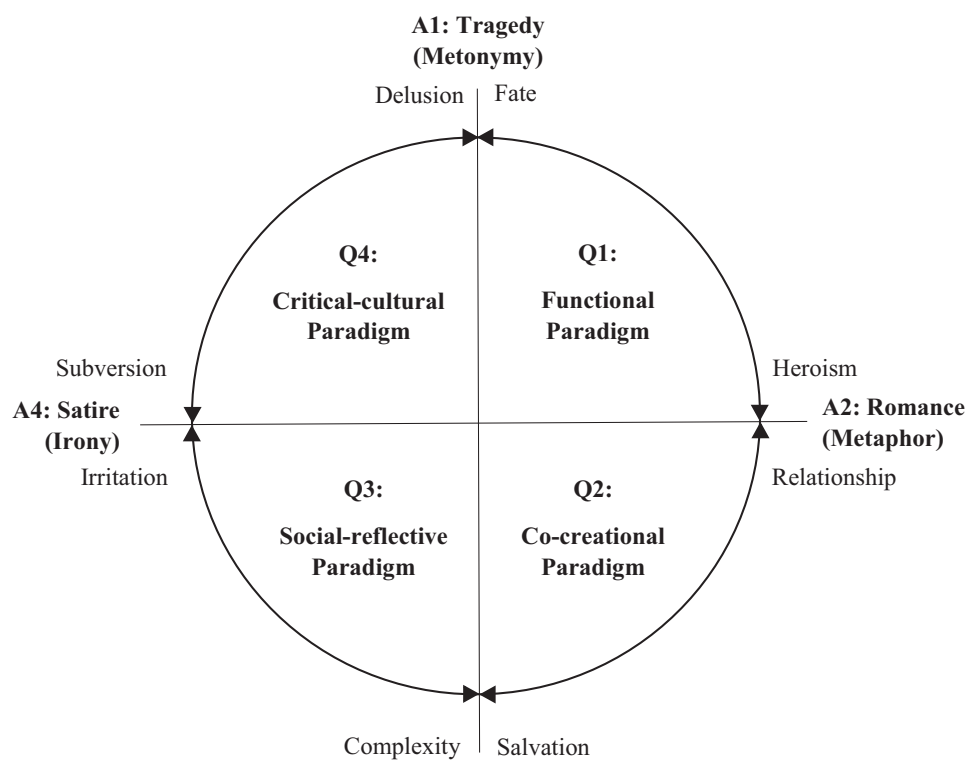

A3: Comedy

(Synecdoche)
Narratives of axiological progress in $\mathrm{PR}$

359

Figure 1.

Narratives of progress in public relations paradigms

progress, and metonymy and metaphor as preferred tropes. While the tragic narrative (A1) provides the structural basis to establish a fatal current state of affairs, a romantic narrative (A2) introduces PR as a heroic agent that, by acquiring extraordinary virtues and skills, can unravel and ultimately transform this fatal state. This combined narrative can be traced back to the founding father of the functional paradigm, Bernays (2011 [1923]). Bernays starts his reflections with a fatal diagnosis of the modern public as easily malleable and compliant victim of organized persuasion. Bernays grounds this argument in metonymical reasoning by referring to law-like assumptions of early mass-psychology. Yet, in a second step, Bernays introduces PR as heroic change agent that can comprehend and transform this situation. To unleash these heroic transformative skills, in earlier writings Bernays (2011 [1923]) stresses the metaphor of PR as invisible, yet powerful patron, apt to protect the public from selfinflicted harm, while in later writings (Bernays 1998 [1977]) PR finds representation as superior conciliator between organization and public. This narrative of a heroic PR that transcends a fatal state is perfected with the four models of PR (Grunig and Grunig, 1992), which follow an underlying narrative of stepwise transformation from a fatal state of mass persuasion toward a desired state of symmetry and win-win.

Current managerial and strategic approaches to PR (e.g. Broom et al., 2013; Grunig and Grunig, 2008; Tench et al., 2017; Zerfass et al., 2018) equally adhere to this combined narrative by starting with a diagnosis of an inferior status quo, metonymical grounded in empirical evidence from management surveys and behavior-based causal models. They then metaphorically introduce new competencies and skills from other disciplines - general leadership and management skills on the one hand, advanced methodological skills from cognitive and behavioral science on the other (Grunig, 2018; Nothhaft, 2016; SeiffertBrockmann, 2018) - as key sources to unfold a heroic narrative of practical professionalization and academic maturation, which will ultimately allow PR to transcend the current state. 
$\mathrm{JCOM}$ 25,4

In sum, we propose that it is the combination of a tragic narrative, which outlines the causalities underlying a fatal status quo, and a romantic narrative, which presents PR as heroic change agent, who achieves superior skills to unravel and intervene into these causalities, that constitutes the normative vision of progress that holds research efforts in the functional paradigm together.

Narrating progress in the co-creational paradigm: between comedy and romance

Scholarship adhering to the co-creational paradigm (Q2), in turn, builds on the oscillation between a comic and romantic plot, concretely salvation and relational maturation as drivers of progress, and synecdoche and metaphor as core tropes. The comic narrative (A3) represents the structural starting ground, as it helps to project a desired future state of salvation despite a present state of societal confusion and error. This projected salvation becomes most obvious in Heath's vision of a "fully functioning society" (2018), yet we can find a similar pattern in visions of social solidarity and betterment as developed by dialogic and community-centered approaches (e.g. Hallahan, 2016; Kent and Taylor, 2002; Kruckeberg and Starck, 1988). To reinforce conviction in a future state of salvation, the preferred trope is the synecdoche, and hence the use of figurative language, which reflects on how situated action can contribute to a larger societal development (pars pro toto).

This narrative structure provides the basis for the subsequent agentic positioning of $\mathrm{PR}$ research. Again, this positioning follows a romantic narrative, yet its emphasis is on relational maturation. Concretely, romantic relational maturation addresses organizational and public agents as committed partners, which together shall adhere to demanding communication principles (e.g. Kent and Taylor, 2002; Taylor and Kent, 2014) in order to contribute to development toward the projected state of salvation. This romantic narrative makes use of metaphorical reasoning by drawing analogies between social-psychological, philosophical and ethical scholarship on intimate interpersonal relationships on the one hand and organization-public-relationships on the other (critically, see Coombs and Holladay, 2015).

Following these considerations, we propose that it is the combination of a comic narrative, which projects a desired future state of salvation, and a romantic narrative, which focuses on mutual relational maturation toward this state, that constitutes the normative vision of progress that holds scholarship in the co-creational paradigm together.

\section{Narrating progress in the social-reflective paradigm: between comedy and satire}

The social-reflective paradigm (Q3) in PR research, in turn, builds on a combination of comic and satirical plot, concretely complexity and irritation as story drivers, and synecdoche and irony as corresponding tropes. Like the co-creational paradigm, it takes a comic plot as a structural narrative basis (A3). However, the emphasis is less on the desired outcome, but on the inscrutable complexity of the ongoing plot. Constructivist social theories (e.g. structuration, new institutional, Luhmannian systems theory, CCO) serve as the common basis to substantiate this inscrutable complexity (Christensen and Christensen, 2018; Falkheimer, 2007; Fredriksson et al., 2013; Heide et al., 2018; Holmström, 2018). Accordingly, this scholarship argues that focal phenomena can only be comprehended by reconstructing them as representations of a larger whole. This is supported by the use of the trope of synecdoche, which mirrors in circular micro-macro-models highlighting a constant interplay of agency and structure, institutionalization and change, functional code and system, talk and text, etc.

This structural narrative of societal development as inscrutably complex is typically combined with a satirical agentic plot (A4). Concretely, scholars representing the 
social-reflective paradigm place central emphasis on irritating established premises on the role and relevance of PR in extant research: first, this concerns the premise of PR agency as deliberate, pointing at the often emergent nature of PR practices (e.g. Gulbrandsen and Just, 2016; Wehmeier, 2006); second, this concerns the premise of control, pointing at the unintended consequences of PR practice (e.g. Christensen and Langer, 2009; Christensen et al., 2008). Both lines of argumentation build on the trope of irony, which becomes obvious in work that either highlights how widely established PR principles - such as consistency or transparency - lead to unintended, even detrimental effects or show how their very opposite - ambiguity and hypocrisy - can have positive effects as well (e.g. Christensen and Christensen, 2018; Christensen et al., 2013; Gulbrandsen, 2019). The overall goal of this endeavor is to irritate narratives of linear progress in PR research and to embrace tensions and contradictions instead to gain a more inclusive picture of the complexity of disciplinary development in PR.

We hence propose that scholarly work contributing to the social-reflective paradigm shares a normative conviction of progress that combines a comic narrative to highlight inscrutable societal complexity, and a satirical narrative to irritate established assumptions on linear progress in order to achieve a more comprehensive overall picture of disciplinary development.

\section{Narrating progress in the critical-cultural paradigm: between tragedy and satire}

The critical-cultural paradigm (Q4), ultimately, combines a tragic and a sativical plot, concretely delusion and subversion as story drivers, and metonymy and irony as preferred tropes to develop its distinct narrative of progress. It shares a tragic narrative (A1) as structural starting ground with the functional paradigm. Yet, on the contrary to the functional paradigm, the accompanying heroic narrative and the corresponding idea of agentic maturation are unmasked as delusion (e.g. Berger, 2005; Davidson, 2016; L'Etang et al., 2016). Scholars argue that it only seems as if a heroic PR can turn the plot. Stressing the trope of metonymy, relentless forces of global hegemony, mass persuasion and inequality driving the tragic narrative are considered to still prevail (e.g. Miller and Dinan, 2008; Weaver, 2016).

Inspired by cultural studies and post-structural reasoning, this scholarship unfolds its agentic narrative, pointing out that the relentless forces underlying the tragic narrative can only be challenged by constant situated deconstruction and contestation (e.g. Edwards, 2006; Gower, 2006). Concretely, this unfolds in a satirical plot (A4), which envisions PR as a subversive change agent that can undermine and unmask corporate hegemony and control for the public's sake and therewith contribute to fragile, yet desirable progress from the status quo. This becomes most visible in ironic tropes of $\mathrm{PR}$ as resistance, activism or agonistic practice (e.g. Berger, 2005; Davidson, 2016; Holtzhausen, 2012).

In sum, we propose that scholarship in the critical-cultural paradigm shares a normative conviction of progress that manifests in a combination of a tragic narrative, which sketches a delusional status quo, and a satirical narrative, which points at opportunities of situational subversion to undermine and transform this status quo.

\section{Discussion}

This conceptual article complements the current debate on disciplinary progress in PR research, which is focused on ontological and epistemological questions. We introduce a narrative approach to highlight the axiological dimension, and hence the question which normative visions of progress underlie divergent PR paradigms. We propose a model, which illustrates how these visions can be traced back to distinct combinations of narratives plots and tropes in extant paradigms of PR research. 
$\mathrm{JCOM}$ 25,4

\section{2}

In the following, we discuss how our model can contribute to the current debate on progress in PR research in three ways: First, it proposes an alternative explanation of paradigm development that may complement extant ontological and epistemological explanations. Second, our model may inspire future empirical research that seeks to investigate how normative convictions of progress can be traced in programmatic PR texts and debates on a narrative level. Third, our article wants to contribute to the debate on progress as such, by providing scholars, students and practitioners with a fresh perspective to question own normative convictions and to openly debate it with fellows.

Regarding the first point, our model can complement current explanations of paradigm development in PR research, as it allows for a reconstruction of how specific axiological convictions of progress create cohesion between ontological and epistemological positions in PR paradigms across time and despite changing theories, concepts and scholars. In case of the functional paradigm, we propose that it is a heroic narrative of transcending a fatal status quo, which holds ever changing variants of managerial ontology and positivist epistemology together. In case of the co-creational paradigm, we propose that it is the romantic narrative of mutual maturation towards comic salvation, which holds changing variants of relational ontology and symbolic epistemology together. In case of the social-reflective paradigm, we propose it is a shared narrative of unmasking social complexity by satirical irritation, which holds changing variants of social theoretical ontology and constructivist epistemology together. Ultimately, in the critical-cultural paradigm, we propose it is a shared narrative of satirical subversion of a current state of delusion, which holds changing variants of critical ontology and deconstructivist epistemology together. What contributes to paradigm development in PR research, we hence contend, is not only a question of ontological and epistemological coherence but also a question of normative adherence to an underlying narrative of progress.

This insight leads us to the second contribution of our paper, namely to provide inspiration for future empirical research that seeks to apply a narrative approach to investigate how normative convictions drive paradigms in PR research. Given the conceptual nature of this article, its primary focus was on deducing propositions. Yet, in Table 1 we outline the key plots, tropes and story drivers that may serve as indicators for empirical research and we have introduced narrative methods literature that may guide this research (foundational Burke, 1941; Frye, 1957; White, 1975; for application to texts in the social sciences, see Czarniawska, 2004). And in our model (Figure 1) we have illustrated how these indicators can be applied to reconstruct specific narrative patterns drawing on selective examples from the PR literature. Future empirical research can substantiate and expand these reflections. A next step could be a systematic sampling and in-depth text-based narrative analysis of programmatic articles, call for papers and positioning papers, which explicitly address disciplinary progress. These documents could be investigated within a specific paradigm on a longitudinal perspective, in order to trace the coherence of narrative patterns over time despite changing theories, concepts and scholars, and/or from a comparative perspective, by identifying typical differences in narrative patterns of texts representing different paradigms. Also interesting, yet empirically more challenging, would be a reconstruction of how specific narrative patterns mirror in positions of rivaling paradigm representatives in the course of confrontation and debate. Article rejoinders and replies could be one way to reconstruct them, recorded podium and plenary discussions, or invited focus groups with selected paradigm representatives could be another.

This leads us to the third contribution of this article, namely the provision of an alternative basis to address cross-paradigmatic tensions and exchange among academics, students and practitioners from an explicitly normative perspective. We believe that a temporary shift from sophisticated ontological and epistemological reflections to more intimate normative 
convictions of progress may open another register of reflection and debate and may help to avoid paradigmatic estrangement and compartmentalization:

Our model provides a fresh perspective to address tensions between paradigm representatives that may root in different normative convictions of how PR shall progress and which mirror in incommensurable narratives: According to our model, one fundamental tension can be traced back to the polarity of a tragic (A1) and a comic plot (A3) as structural narrative starting points, and the polarity between a romantic (A2) and a satirical agentic plot (A4). These two polarities can provide much explanation of current reservation and controversy between representatives of different paradigms in PR: While some have their convictions of a disciplinary fatal, yet determinable status quo that urgently needs to be overcome, others rather adhere to an inscrutable status quo, yet share the conviction of incremental development toward betterment. Further, while some envision the discipline as potent romantic change agent (A2), others see it as satirical interrogator. As White (1975) argues these opposing views are connected to innermost normative convictions of how one evaluates the status quo of society, as well as the scope, urgency and capacity to change it. We hope that our model may provide a first basis to explicate and debate these fundamental convictions with fellow scholars representing divergent paradigms, but also with practitioners or students in seminars, and hence contribute to a more inclusive debate on how axiology shapes perspectives on disciplinary progress.

Despite tensions, our model may ultimately provide a fresh perspective to reflect on opportunities of exchange between different paradigmatic positions in PR research. First, it may explain why, despite evident normative tensions, exchange between the most established functional (Q1) and co-creational paradigm (Q2) is quite frequent, particularly in case of co-creational concepts - such as dialogic and relationship principles - getting appropriated by functional scholarship. This may be the case due to a shared overarching romantic plot (A2) - and hence a commensurable vision of disciplinary progress from linear agentic maturation, yet ongoing normative tensions due to different emphasis on either heroic or relational capabilities of this agent (e.g. Botan and Taylor, 2004; Grunig, 2018). A similar argument may also apply to the other pole of our model, namely the shared conceptualization of PR as counter-intuitive satirical agent (A4) of the social-reflective (Q3) and the critical-cultural paradigm (Q4). This may provide an additional source of reflection for growing exchange between these paradigms (e.g. Edwards, 2018; Ihlen and Fredriksson, 2018; Ihlen and Verhoeven, 2012), concretely analytic scholarship interested in the unintended effects of PR practice on the one hand, and cultural-critical scholarship on the other hand, which reflects on how these effects can be used for subversive action. Lastly, shared structural narratives may provide a basis for axiological reflection on further crossparadigmatic exchange. The tragic narrative (A1) shared by the functional (Q1) and the critical-cultural paradigm (Q4), mainly fulfills a mutually challenging normative function: While the representatives of the functional paradigm strive to overcome a present tragic state, the critical-cultural paradigm repeatedly unmasks these ambitions as delusion (L'Etang et al., 2016), and hence spurs new functional efforts. The comic narrative (A3) shared by the co-creational $(\mathrm{Q} 2)$ and social-reflective paradigm $(\mathrm{Q} 3)$, in turn, may rather have a mutually complementary normative function: While the social-reflective paradigm may help the co-creational paradigm to better understand the complexities and unintended effects of demanding communication principles in practice, the latter may provide the former with a generally positive perspective of development toward betterment, despite the current inscrutable state.

In sum, we hope that our model provides a complementary perspective to the debate on disciplinary progress in $\mathrm{PR}$, as it sketches a way how to explicate the often implicit normative convictions by means of narrative inquiry to empirical PR research, disciplinary debate and education.
Narratives of axiological progress in PR

363 
$\mathrm{JCOM}$ 25,4

364

\section{References}

Bardhan, N. and Weaver, C.K. (2010), Public Relations in Global Cultural Contexts: Multi-Paradigmatic Perspectives, Routledge, New York, NY.

Berger, B.K. (2005), "Power over, power with, and power to relations: critical reflections on public relations, the dominant coalition, and activism", Journal of Public Relations Research, Vol. 17 No. 1, pp. 5-28, doi: 10.1207/s1532754xjprr1701_3.

Bernays, E.L. (1998 [1977]), “Counselling not communication”, IPRA Review, Vol. 20 No. 1, pp. 28-32.

Bernays, E.L. (2011 [1923]), Crystallizing Public Opinion, Ig Publishing, New York, NY.

Booth, W.C. (1975), A Rhetoric of Irony, University of Chicago Press, Chicago, IL.

Botan, C.H. and Taylor, M. (2004), "Public relations: state of the field", Journal of Communication, Vol. 54 No. 4, pp. $645-661$.

Broom, G.M., Sha, B.-L., Seshadrinathan, S., Center, A.H. and Cutlip, S.M. (2013), Cutlip and Center's Effective Public Relations, 11th ed., Pearson, Harlow.

Burke, K. (1941), "Four master tropes", The Kenyon Review, Vol. 3 No. 4, pp. 421-438.

Burke, K. (1969), A Rhetoric of Motives, University of California Press, Berkeley, CA.

Campbell, L. (2008 [1949]), The Hero with a Thousand Faces, Princeton University Press, Princeton, NJ.

Christensen, E. and Christensen, L.T. (2018), "Dialogics of strategic communication", Corporate Communications: An International Journal, Vol. 23 No. 3, pp. 438-455, doi: 10.1108/CCIJ-082017-0073.

Christensen, L.T. and Langer, R. (2009), "Public relations and the strategic use of transparency: consistency, hypocrite, and corporate change", in Heath, R.L., Toth, E.L. and Waymer, D. (Eds), LEA's Communication Series: II. Rhetorical and Critical Approaches to Public Relations, 2nd ed., Routledge, London, pp. 129-153.

Christensen, L.T., Morsing, M. and Cheney, G. (2008), Corporate Communications: Convention, Complexity, and Critique, SAGE, Los Angeles, CA.

Christensen, L.T., Morsing, M. and Thyssen, O. (2013), "CSR as aspirational talk", Organization, Vol. 20 No. 3, pp. 372-393, doi: 10.1177/1350508413478310.

Coombs, T. and Holladay, S.J. (2015), "Public relations' 'relationship identity' in research: enlightenment or illusion”, Public Relations Review, Vol. 41 No. 5, pp. 689-695, doi: 10.1016/j. pubrev.2013.12.008.

Curtin, P.A. (2012), "Public relations and philosophy: parsing paradigms", Public Relations Inquiry, Vol. 1 No. 1, pp. 31-47, doi: 10.1177/2046147X11422150.

Curtin, P.A. and Gaither, T.K. (2005), "Privileging identity, difference, and power: the circuit of culture as a basis for public relations theory", Journal of Public Relations Research, Vol. 17 No. 2, pp. 91-115, doi: 10.1207/s1532754xjprr1702_3.

Czarniawska, B. (2004), Narratives in Social Science Research, SAGE, London.

Davidson, S. (2016), "Public relations theory: an agonistic critique of the turns to dialogue and symmetry", Public Relations Inquiry, Vol. 5 No. 2, pp. 145-167, doi: 10.1177/ $2046147 X 16649007$.

Dühring, L. (2015), "Lost in translation? On the disciplinary status of public relations", Public Relations Inquiry, Vol. 4 No. 1, pp. 5-23, doi: 10.1177/2046147X14563564.

Edwards, L. (2006), "Rethinking power in public relations", Public Relations Review, Vol. 32 No. 3, pp. 229-231, doi: 10.1016/j.pubrev.2006.05.013.

Edwards, L. (2012), "Defining the 'object' of public relations research: a new starting point", Public Relations Inquiry, Vol. 1 No. 1, pp. 7-30, doi: 10.1177/2046147X11422149.

Edwards, L. (2018), Understanding Public Relations: Theory, Culture and Society, SAGE, Los Angeles, CA. 
Falkheimer, J. (2007), "Anthony Giddens and public relations: a third way perspective", Public Relations Review, Vol. 33 No. 3, pp. 287-329, doi: 10.1016/j.pubrev.2007.05.008.

Ferguson, M.A. (2018 [1984]), "Building theory in public relations: interorganizational relationships as a public relations paradigm", Journal of Public Relations Research, Vol. 30 No. 4, pp. 164-178, doi: 10.1080/1062726X.2018.1514810.

Fisher, W. (1994), "Narrative rationality and the logic of scientific discourse", Argumentation, Vol. 8, pp. 21-32.

Fleck, L. (1981 [1935]), Genesis and Development of a Scientific Fact, University of Chicago Press, Chicago, IL.

Fredriksson, M., Pallas, J. and Wehmeier, S. (2013), "Public relations and neo-institutional theory", Public Relations Inquiry, Vol. 2 No. 2, pp. 183-203, doi: 10.1177/2046147X13485956.

Frye, N. (1957), Anatomy of Criticism: Four Essays, Princeton University Press, Princeton, NJ.

Gower, K.K. (2006), "Public relations research at the crossroads", Journal of Public Relations Research, Vol. 18 No. 2, pp. 177-190, doi: 10.1207/s1532754xjprr1802_6.

Grinter, A. (2017), "Narrative and history: Hayden White's objections to scientistic changes to the study of history", Cosmos and History, Vol. 13 No. 1, pp. 222-239.

Grunig, J.E. (2018), "Strategic behavioral paradigm", in Heath, R.L. and Johansen, W. (Eds), The International Encyclopedia of Strategic Communication, Wiley, New York, NY, doi: 10.1002/ 9781119010722.iesc0171.

Grunig, J.E. and Grunig, L.A. (1992), "Models in public relations and communication", in Grunig, J.E. (Ed.), Excellence in Public Relations and Communication Management, Lawrence Erlbaum, Hillsdale, NJ, pp. 285-325.

Grunig, J.E. and Grunig, L.A. (2008), "Excellence theory in public relations: past, present, and future", in Zerfass, A., Ruler, B. and Sriramesh, K. (Eds), Public Relations Research: European and International Perspectives and Innovations, Verlag für Sozialwissenschaften, Wiesbaden, DE, pp. 327-347.

Gulbrandsen, I.T. (2019), "The co-presence of clarity and ambiguity in strategic corporate communication: an exploratory study", International Journal of Strategic Communication, Vol. 13 No. 2, pp. 95-109, doi: 10.1080/1553118X.2019.1575222.

Gulbrandsen, I.T. and Just, S.N. (2016), Strategizing Communication: Theory and Practice, Samfundslitteratur, Copenhagen, DK.

Hallahan, K. (2016), “'Community' as a foundation for public relations theory and practice”, Annals of the International Communication Association, Vol. 28 No. 1, pp. 233-279, doi: 10.1080/23808985. 2004.11679037.

Hamilton, A.C. (1990), Nothrop Frye. Anatomy of His Criticism, University of Toronto Press, Toronto, CD.

Heath, R.L. (2018), "Fully functioning society", in Heath, R.L. and Johansen, W. (Eds), The International Encyclopedia of Strategic Communication, Wiley, New York, NY, pp. 1-9, doi: 10. 1002/9781119010722.iesc0078.

Heide, M., von Platen, S., Simonsson, C. and Falkheimer, J. (2018), "Expanding the scope of strategic communication: towards a holistic understanding of organizational complexity", International Journal of Strategic Communication, Vol. 12 No. 4, pp. 452-468, doi: 10.1080/1553118X.2018. 1456434.

Holmström, S. (2018), "On Luhmann: reframing public relations as part of society's evolutionary learning processes", in Ihlen, Ø. and Fredriksson, M. (Eds), Public Relations and Social Theory: Key Figures, Concepts and Developments, Routledge, New York, NY, pp. 39-60.

Holtzhausen, D.R. (2012), Public Relations as Activism: Postmodern Approaches to Theory \& Practice. Communication Series, Routledge, New York, NY.

Narratives of axiological progress in $\mathrm{PR}$

(1) 
$\mathrm{JCOM}$ 25,4

Ihlen, Ø. and Fredriksson, M. (Eds), (2018), Public Relations and Social Theory: Key Figures and Concepts, 2nd ed., Routledge, New York, NY.

Ihlen, Ø. and van Ruler, B. (2007), "How public relations works: theoretical roots and public relations perspectives”, Public Relations Review, Vol. 33 No. 3, pp. 243-248, doi: 10.1016/j.pubrev.2007. 05.001 .

Ihlen, Ø. and Verhoeven, P. (2012), “A public relations identity for the 2010s”, Public Relations Inquiry, Vol. 1 No. 2, pp. 159-176, doi: 10.1177/2046147X11435083.

Jameson, F. (1975), "Magical narratives: romance as genre”, New Literary History, Vol. 7 No. 1, p. 135, doi: $10.2307 / 468283$.

Johansen, T.S. (2012), "The narrated organization: implications of a narrative corporate identity vocabulary for strategic self-storying", International Journal of Strategic Communication, Vol. 6 No. 3, pp. 232-245, doi: 10.1080/1553118X.2012.664222.

Kent, M.L. (2015), "The power of storytelling in public relations: introducing the 20 master plots", Public Relations Review, Vol. 41 No. 4, pp. 480-489, doi: 10.1016/j.pubrev.2015.05.011.

Kent, M.L. and Taylor, M. (2002), "Toward a dialogic theory of public relations", Public Relations Review, Vol. 28 No. 1, pp. 21-37, doi: 10.1016/S0363-8111(02)00108-X.

Kruckeberg, D. and Starck, K. (1988), Public Relations and Community: A Reconstructed Theory, Praeger, New York, NY.

Kuhn, T.S. (1991), "The natural and the human sciences", in Hiley, D.R., Bohman, J.F. and Shusterman, R. (Eds), The Interpretive Turn: Philosophy, Science, Culture, Cornell University Press, Ithaca, NY, pp. 17-24.

Kuhn, T.S. (2012 [1962]), The Structure of Scientific Revolutions, University of Chicago Press, Chicago, IL.

Lakoff, G. and Johnson, M. (1980), Metaphors We Live by, University of Chicago Press, Chicago, IL.

L'Etang, J., McKie, D., Snow, N. and Xifra, J. (Eds), (2016), The Routledge Handbook of Critical Public Relations, Routledge, London.

Masterman, M. (1970), "The nature of a paradigm”, in Lakatos, I. and Musgrave, A. (Eds), Criticism and the Growth of Knowledge, Cambridge University Press, Cambridge, pp. 59-90.

McCloskey, D. (1998), The Rhetoric of Economics, 2nd ed., University of Wisconsin Press, Madison, Wisconsin, WI.

Miller, D. and Dinan, W. (2008), A Century of Spin: How Public Relations Became the Cutting Edge of Corporate Power, Pluto Press, London, Ann Arbor, MI.

Nothhaft, H. (2016), “A framework for strategic communication research: a call for synthesis and consilience", International Journal of Strategic Communication, Vol. 10 No. 2, pp. 69-86, doi: 10. 1080/1553118X.2015.1124277.

Nothhaft, H., Werder, K.P., Verčič, D. and Zerfass, A. (2018), "Strategic communication: reflections on an elusive concept", International Journal of Strategic Communication, Vol. 12 No. 4, pp. 352-366, doi: 10.1080/1553118X.2018.1492412.

Palmlund, I. (2009), "Risk and social dramaturgy", in Heath, R.L. and OHair, H.D. (Eds), Handbook of Risk and Crisis Communication, Routledge, New York, NY, pp. 192-204.

Panther, K.-U. and Radden, G. (Eds), (1999), Metonymy in Language and Thought, Benjamins, Amsterdam, NL.

Pasadeos, Y., Berger, B. and Renfro, R.B. (2010), "Public relations as a maturing discipline: an update on research networks", Journal of Public Relations Research, Vol. 22 No. 2, pp. 136-158, doi: 10. 1080/10627261003601390.

Pearson, R. (1990), "Perspectives on public relations history", Public Relations Review, Vol. 16 No. 3, pp. 27-38, doi: 10.1016/s0363-8111(05)80067-0. 
Roper, J. (2005), "Symmetrical communication: excellent public relations or a strategy for hegemony?", Journal of Public Relations Research, Vol. 17 No. 1, pp. 69-86, doi: 10.1207/s1532754xjprr1701_6.

Rule, J.B. (1997), Theory and Progress in Social Science, Cambridge University Press, Cambridge.

Sallot, L.M., Lyon, L.J., Acosta-Alzuru, C. and Ogata Jones, K. (2003), "From aardvark to zebra: a new millennium analysis of theory development in public relations academic journals", Journal of Public Relations Research, Vol. 15 No. 1, pp. 27-90, doi: 10.1207/S1532754XJPRR1501_2.

Seiffert-Brockmann, J. (2018), "Evolutionary psychology. A framework for strategic communication research", International Journal of Strategic Communication, Vol. 12 No. 4, pp. 417-432, doi: 10. 1080/1553118X.2018.1490291.

Shneider, A.M. (2009), "Four stages of a scientific discipline; four types of scientist", Trends in Biochemical Sciences, Vol. 34 No. 5, pp. 217-223, doi: 10.1016/j.tibs.2009.02.002.

Sisco, H.F., Collins, E.L. and Zoch, L.M. (2011), "Breadth or depth? A content analysis of the use of public relations theory", Public Relations Review, Vol. 37 No. 2, pp. 145-150, doi: 10.1016/j. pubrev.2010.10.006.

Taylor, M. and Kent, M.L. (2014), "Dialogic engagement: clarifying foundational concepts", Journal of Public Relations Research, Vol. 26 No. 5, pp. 384-398, doi: 10.1080/1062726X.2014.956106.

Tench, R., Verčič, D., Zerfass, A., Moreno, Á. and Verhoeven, P. (2017), Communication Excellence: How to Develop, Manage and Lead Exceptional Communications, Palgrave Macmillan, London, doi: 10.1007/978-3-319-48860-8.

Vasquez, G.M. (1993), “A homo narrans paradigm for public relations: combining Bormann's symbolic convergence theory and Grunig's situational theory of publics", Journal of Public Relations Research, Vol. 5 No. 3, pp. 201-216, doi: 10.1207/s1532754xjprr0503_03.

Watson, C. (2015), Comedy and Social Science: Towards a Methodology of Funny, Routledge, London, Florence, IT.

Weaver, C.K. (2016), “A Marxist primer for critical public relations scholarship”, Media International Australia, Vol. 160 No. 1, pp. 43-52, doi: 10.1177/1329878X16650735.

Wehmeier, S. (2006), "Dancers in the dark: the myth of rationality in public relations", Public Relations Review, Vol. 32 No. 3, pp. 213-220, doi: 10.1016/j.pubrev.2006.05.018.

White, H.V. (1975), Metahistory: the Historical Imagination in Nineteenth-Century Europe, Johns Hopkins University Press, Baltimore, MD.

White, H.V. (1980), "The value of narrativity in the representation of reality", Critical Inquiry, Vol. 7 No. 1 , pp. 5-27.

Wilson, E.O. (1998), Consilience. The Unity of Knowledge, Vintage, New York, NY.

Winkler, P. and Etter, M. (2018), "Strategic communication and emergence: a dual narrative framework", International Journal of Strategic Communication, Vol. 12 No. 4, pp. 382-398, doi: 10.1080/1553118X.2018.1452241.

Zerfass, A., Verčič, D., Nothhaft, H. and Werder, K.P. (2018), "Strategic communication: defining the field and its contribution to research and practice", International Journal of Strategic Communication, Vol. 12 No. 4, pp. 487-505, doi: 10.1080/1553118X.2018.1493485.

\section{Corresponding author}

Peter Winkler can be contacted at: peter.winkler@plus.ac.at

For instructions on how to order reprints of this article, please visit our website:

www.emeraldgrouppublishing.com/licensing/reprints.htm

Or contact us for further details: permissions@emeraldinsight.com

Narratives of axiological progress in $\mathrm{PR}$ $-$ 